This is the author's Post-print version (final draft post-refereeing as accepted for publication by the journal). The definitive, peer-reviewed and edited version of this article is published as: De Meester E. and van Ham M. (2009) Symmetry and asymmetry in working and commuting arrangements between partners in the Netherlands: does the residential context matter? Environment and Planning A 41, 2181-2200. http://dx.doi.org/10.1068/a41246

\title{
Symmetry and asymmetry in working and commuting arrangements between partners in The Netherlands. Does the residential context matter?
}

\author{
Edith de Meester* \& Maarten van Ham** \\ *University of Amsterdam, Amsterdam Institute for Metropolitan and International \\ Development Studies, Nieuwe Prinsengracht 130, 1018 VZ Amsterdam, NL. Phone +31 (0)20 \\ 5251211, Fax +31 (0)20 5254051 E-mail: e.s.demeester@uva.nl \\ **University of St Andrews, School of Geography \& Geosciences, Irvine Building, North \\ Street, St Andrews, Fife, KY16 9AL, UK. Phone +44 (0)1334 463912, Fax +44 (0)1334 \\ 463949, E-mail: maarten.vanham@st-andrews.ac.uk
}

\begin{abstract}
Time spent on work and commuting within dual earner households is often analysed separately for individuals, but this does no justice to the reality of dual earner households where decisions on work and commuting are made in a household context. This article reports on a quantitative study of the impact of the residential context on working arrangements and commuting arrangements of partners in couple and family households. Using multinomial logistic regression we analysed data from the Netherlands Housing Demand Survey (2002) and the ABF Real Estate Monitor (2004). The results show a (gendered) effect of residential location in terms of degree of urbanization and job access on both working and commuting arrangements. Good access to jobs makes it more likely that couples have a symmetric full-time working arrangement and also more likely that both partners work far away. Those in symmetric full-time working arrangements are also those most likely to be in symmetric close commuting arrangements. This finding reflects the substantial time pressure on such households.
\end{abstract}

Key words: commuting, working hours, households, gender inequality, opportunity structure, residential context, the Netherlands

\section{Introduction}

The rise in female labour market participation in The Netherlands has resulted in the one-anda-half earner model to take over from the male breadwinner model as being the dominant earner model (Visser, 2002; Knijn, 2003; Duyvendak \& Stavenuiter, 2004). One in four dual earner households now even combine two fulltime jobs (Van der Valk, 2005). On average, dual earner households do not just spend more time on working than one earner households, but also on commuting. As a result, the so-called life/work balance of dual earners often leans over to the work side (McDowell, 2004; Jarvis, 2005; Presser, 2006). 
Qualitative research has given us insight into the daily struggle by dual earners to run the household when time is scarce. Often, careful synchronization of household members' schedules is required to be able to carry out all paid and unpaid duties (Hochschild \& Machung, 1989; Clarkberg \& Moen, 2001; Moen, 2003; Schwanen, 2006; 2007). Inspired by Hägerstrand (1970), feminist geographers have emphasised the importance of the spatial context in the shaping of daily routines of households (Tivers, 1985; Hanson \& Pratt 1988; Droogleever Fortuijn, 1993; Hanson \& Pratt, 1995; Jarvis 1999; Karsten, 2003; Moen, 2003; Jarvis, 2005). The spatial context may facilitate or constrain people's behaviour.

Although qualitative studies indicate that many decisions on time expenditure, including work and commuting, are made on the household level, most quantitative studies tend to focus on individuals. There are large (separate) bodies of literature studying working and commuting decisions on the individual level. From such studies we know that (combinations of) working time and commuting time on the individual level varies according to socio-demographic and spatial variables (Schwanen \& Dijst, 2002). To our knowledge, there are no quantitative studies analysing time spent on paid work and time spent on commuting in a household context. This does no justice to the reality of a lot of dual earner households where working arrangements and commuting arrangements can be expected to be interconnected.

This paper contributes to the existing literature by using quantitative data representative of the Netherlands population to study factors associated with different working and commuting arrangements on the household level. We pay specific attention to the role of the residential context in shaping working and commuting arrangements of partners in couple and family households. By using data on households living in a variety of residential contexts, we aim to increase our insight in the role of the residential context in facilitating or constraining working and commuting arrangements between partners. Such insight will enhance our understanding of how individual careers are shaped. The remainder of this paper is structured as follows. First, the literature review links literatures on commuting and working, emphasising the role of the household context and the spatial context. Next follows a description of data and methods used to analyse working and commuting arrangements. After a description of the results, the concluding section discusses the contribution of this paper to the literature, limitations of the study and potential implications of the results for labour market policy.

\section{Literature and hypotheses}

In this literature review we will combine the two literatures studying working and commuting decisions on the individual level and derive hypotheses on the effect of the spatial context on working and commuting arrangements of couples. Before we can derive hypotheses we need to define working and commuting arrangements (see the data and methods section for a detailed operationalisation). There are numerous ways to characterize the divisions of paid work between partners (Warren, 2007). Because of the importance of part-time work for women in The Netherlands (Visser, 2002) we distinguished between full-time jobs, large parttime jobs and small part-time jobs. Based on this division and by combining working hours of two partners we have defined five working arrangements: the symmetric fulltime arrangement in which both partners hold a full-time job; the female large part-time arrangement, in which the male has a fulltime job and the female holds a large part-time job; the female small parttime arrangement in which the male has a fulltime job and the female a small part-time job; the male part-time arrangement in which the male holds a part-time job and the female holds a 
fulltime or part-time job; and the traditional male breadwinner arrangement in which the male partner holds a fulltime job and the female partner has no job.

Based on the commuting time of each working partner and symmetry between commuting times of partners we also defined five types of commuting arrangements (see Van Ommeren, 1996; Van Ham, 2002): symmetric close, referring to arrangements in which both partners spend little time on commuting; symmetric far referring to arrangements in which both partners have long commutes; female very close referring to an arrangement in which the female partner has a very short commute and the male partner has a long commute; female close, referring to arrangements in which the female partner has a short commute and the male partner has a long commute; and other, a rest category, consisting of all remaining combinations, including arrangements in which the commuting time of females is equal or higher than their partner's commuting time.

\section{The relationship between working and commuting time}

The basic assumption underlying this paper is that decisions on the time people spend on working and commuting are interconnected, not only at the level of individuals, but also on the level of households. The amount of time people spend in paid work is both a means to accumulate human capital and to generate returns on human capital. Time spent in paid work is also a way to realise self-actualisation. The time spent on commuting predominantly serves as a means to get to a certain job and can therefore be regarded as a time investment that enables time expenditure in the paid labour force.

According to work by Schwanen and Dijst (2002) there is a positive relationship between commuting time and hours spent on paid work on the individual level (Schwanen \& Dijst, 2002). Working more hours increases the likelihood of having a longer commute. For a small part-time job it is simply not worth having a long commute. From this perspective, we can expect that also on the household level time spent on commuting is positively related to time spent on work. We expect that a symmetric fulltime working arrangement increases the likelihood of a symmetric far commuting arrangement. We also expect that a female part-time working arrangement increases the likelihood of a female close or female very close commuting arrangement. On the other hand, owing to constraints from a limited time budget, more time spent in paid work leaves less time to spend on commuting. Time spent on commuting might therefore be substituted by time spent on paid work. From this time budget perspective, a competing hypothesis is put forward, which is that an arrangement in which both partners work fulltime decreases the likelihood of a commuting arrangement in which both partners also spend much time on commuting - the symmetric far commuting arrangement.

\section{Socio-economic characteristics and working and commuting arrangements}

Especially the levels of education of working partners in couple and family household can be expected to be important in shaping working and commuting arrangements. The more human capital - education, training and work experience - people accumulate over their life course the higher the expected returns in wages (Becker, 1962). Economists often express workers level of human capital as a worker's potential wage rate (potential earnings per hour) (Blundell \& MaCurdy, 1999). The more human capital a worker has accumulated, each hour spent outside the labour market is more valuable, resulting in more working hours. This is known as the substitution effect (Becker, 1965; Gronau, 1977). Workers with a high level of human capital are likely to have a high income compared to others. Having a high income enables people to consume and produce more final goods, which takes time and leads to a decline in working hours, known as the income effect. 
With respect to time spent on paid work on the individual level, it was shown for The Netherlands that for women having a high level of education increases the number of hours they work (De Meester et al., 2007). Van der Lippe and Siegers (1994) found a positive effect of women's (potential) wage rate on working hours, but others found no effect (De Meester et al., 2007). For men, a higher (potential) wage rate lowers their weekly hours of paid work (Van der Lippe \& Siegers, 1994, De Meester et al., 2007). With respect to commuting, having a high level of education and having a high wage rate have been found to result in longer commuting trips (Rouwendal \& Nijkamp, 2004; Van Ham \& Hooimeijer, 2005). Since highly paid jobs tend to be more widely dispersed than low paid jobs, the highly educated workers need to travel further to reach a suitable job (Van Ham, 2002). In accordance with findings from previous research we expect that a higher educational level and a higher wage rate both lead to more time spent on working and commuting.

According to new home economics, it is more profitable for a household as a whole to divide tasks into paid productive and unpaid reproductive categories (Mincer \& Polachek, 1974; Becker, 1981). This task division enables the partner with the most human capital to maximize his or her earnings, and the other partner to specialize in reproductive tasks. On the household level, differences in time spent on paid work and commuting are expected to differ according to differences in human capital between the partners. Irrespective of gender, the partner with the highest earning potential is expected to work the most hours and to spend the most time on commuting, whereas the other partner is expected to spend less time on both activities. Differences in human capital between the partners are therefore expected to increase the likelihood of asymmetrical working and commuting arrangements.

Homeowners are known to be restricted in their spatial flexibility (Van Ham \& Hooimeijer, 2005), which is likely to influence working and commuting arrangements. Homeowners are both financially and spatially more tied than renters. Mortgages are often based on two full-time incomes and therefore, homeownership can be expected to have a positive impact on the time spent on paid work in a household. Homeownership also limits household's spatial flexibility because of the high transaction costs involved in a move (Helderman et al., 2006). Furthermore, homeowners might be less likely to move because they are more attached to their residential location and their residence than renters. As a result of limited spatial flexibility in terms of moving house, homeowners might be more likely to choose long commutes than renters (Van Ham \& Hooimeijer, 2005). Being a homeowner is therefore expected to increase the likelihood of a symmetric fulltime working arrangement and a commuting arrangement in which one or both partners have a far commute.

\section{The presence of children and gender roles}

On average, women spend less time on paid work and have shorter commutes than men, especially when there are young children in the household (Madden, 1981; Turner \& Niemeier, 1997, Schwanen et al., 2002). The household responsibility thesis explains these differences through gender differences in the division of household tasks (JohnstonAnumonwo, 1992). In most families women spend more time on domestic tasks than men, even when the number of working hours is equal (Tivers, 1985; Droogleever Fortuijn, 1993; Karsten, 2003; Jarvis, 2005). Among mothers in the Netherlands a culture of care prevails, which gives priority to family over labour career (Keuzenkamp \& Hooghiemstra, 2000; Van Wel \& Knijn, 2006; Van der Lippe et al., 2006). This culture may reinforce asymmetric commuting arrangements between partners even more. Bringing up children does not only take time, but also costs money. When roles within the household are allocated in a traditional way, the male's labour career gets priority, which not only increases asymmetry in commuting arrangements, but also in work arrangements. We expect that having children, and 
in particular young children, increases the likelihood of gendered working and commuting arrangements.

\section{Other background characteristics}

Religiosity is known to correlate with more traditional values towards task division and the upbringing of children. It can be expected than religiosity in The Netherlands is more prevalent in less urbanized areas than in urbanized areas. This spatial concentration of more traditional values might obscure effects from the residential context that have our primary interest. Religiosity is commonly used in models of female labour force participation as a proxy for traditional values (Van Ham \& Büchel, 2006). We expect that religiosity increases the likelihood of gendered working and commuting arrangements, especially the likelihood of a female small part time arrangement and the traditional male breadwinner model.

The spatial concentration of non-western ethnic minorities in the larger cities in the Netherlands might also interfere with the effects of the spatial context. It has been shown, for the United States, that women from ethnic minorities on average have longer commutes than other women because of a spatial mismatch between where they live and where jobs are located (MacLafferty \& Preston, 1992; Johnston-Anumonwo, 1992). Although the spatial mismatch hypothesis does not seem to apply to ethnic minorities in The Netherlands, nonwestern immigrants do encounter more restrictions on the labour market than native Dutch and western immigrants (Andriessen et al., 2007). Non-western immigrants in The Netherlands believe they have to perform better than others because of discrimination and they are less likely than others to have permanent employment and are among the first to be made redundant in times of economic recession (Andriessen et al., 2007). Because non western immigrants are more likely to have longer commutes (reflecting that it is harder to find a job) and to work more hours per week (to stay in a job) we expect them to be more likely to be in a symmetric fulltime working arrangement and a symmetric far commuting arrangement than others.

\section{Residential context: opportunities and constraints}

The spatial configuration of dual earner households - one residential location and two work locations - has important consequences for their working and commuting arrangements. The migration tolerance of dual earners is limited as moving for the career of one partner might have a negative effect on the career of the other partner. Dual earners therefore stretch their commuting tolerance to be able to reach as many jobs as possible without having to move (Brun \& Fagnani, 1994; Green, 1997; Van Ham, 2002). We hypothesise that the quality of the opportunity structure of jobs, services and transport opportunities in the residential context hampers or facilitates people in their time space behaviour and may therefore lead to certain working and commuting arrangements.

Large cities contain the richest spatial opportunity structures in terms of density and variety of amenities, combined with a high quality public transport system (including rail connections to other cities). Such a rich opportunity structure can be expected to facilitate the combination of having a paid job and carrying out day-to-day duties. In addition, large cities offer superior access to job opportunities within short commuting distances, ideal for those with a low commuting tolerance (Droogleever Fortuijn, 1993; Jarvis, 2005). We therefore expect that living in a large city increases the likelihood of symmetric fulltime working arrangements and symmetric short commuting arrangements. We expect that this is in particular the case for living in very large cities, because of the density of jobs, amenities and transport system.

For those with a commuting tolerance up to 45 minutes, suburban areas between the four major cities in the Netherlands offer the greatest access to jobs (Van Ham, 2002). There 
are two competing hypotheses with regard to the impact of living in a suburban area on working and commuting by women. The spatial entrapment hypothesis suggests that women in suburban locations are spatially entrapped because of their domestic responsibilities. As a consequence, their job search area is limited, excluding them from more suitable jobs at larger distances (Hanson \& Johnston, 1985). From this perspective it is expected that living in a suburban location with a high job access within 45 minutes increases the likelihood of gendered asymmetric working and commuting arrangements. Other findings do not support the spatial entrapment thesis. England (1993) for instance, has shown that commuting times for women in suburban areas largely vary and for various reasons. The dual earner strategy hypothesis suggests that dual earners choose strategic suburban residential locations in between larger cities because these are the locations with the highest job access for those willing to invest in commuting (Van Ham et al., 2001a, 2001b; Van Ham, 2002). From a dual earner strategy perspective it is therefore expected that living in an area with a high job access within 45 minutes increases the likelihood of symmetric fulltime working arrangements and symmetric far commuting arrangements.

We have to be careful to conclude that certain residential locations have a causal effect on certain working and commuting arrangements. Van Ham (2002) has suggested that dual earner households choose strategic residential locations because they facilitate certain arrangements. Similarly, Costa \& Kahn (2000) have demonstrated that highly educated dual earners or 'power couples' increasingly choose to live in large metropolitan areas, because these areas enable them to pursue two careers within reasonable commuting distances. So it is the question to what extent a positive association between residential context and working and commuting arrangements can be interpreted as being the effect of the former on the latter. We argue that because some couples choose to live in a certain residential context which facilitates their preferred working and commuting arrangements the residential context is still instrumental to the arrangements.

The Randstad region (including the cities of Amsterdam, The Hague, Rotterdam, Utrecht and the Green Heart', the area between the four largest cities) offers very good access to jobs as more than one large city can be reached within reasonable commuting time (van Ham, 2002). It was demonstrated by Van Ham and Hooimeijer (2005) that people living in the Randstad region have longer commutes than people living elsewhere in the Netherlands and are less likely to move for their work. Therefore, paradoxically, commuting times in this job rich area are higher than in less urbanised areas. This was already predicted by Clark and Kuijpers-Linde (1994) who found that the transition into a polynucleated urban system would lead to more instead of less commuting. One of the reasons is the choice of strategic residential locations by dual earners, and another reason is congestion (Clark \& KuijpersLinde, 1994). We therefore expect that living in the Randstad region increases the likelihood of a symmetric far commuting arrangement, or a commuting arrangement where one of the partners has a long commute.

It should be noted that traditional values towards working and commuting arrangements could be overrepresented outside the larger cities and modern values could be overrepresented in cities, reinforced by selective migration. Differences in working and commuting arrangements between spatial contexts might be the result of differences in lifestyle orientation, which may be spatially concentrated. From a lifestyle perspective we expect that dual earner households in larger cities have more often modern values, resulting in a more egalitarian division between paid and unpaid work. It was demonstrated by De Meester and colleagues (2007) that men living in large cities work fewer hours when having children; this might be the result of modern values. We therefore put forward the hypothesis that living in a large city increases the likelihood of symmetry in working and commuting 
arrangements. In particular we expect that living in one of the big cities increases the likelihood of a male part-time working arrangement.

\section{Data \& Methods}

The data were assembled from the 2002 Housing Demand Survey (WBO) of the Ministry of Housing, Spatial Planning and the Environment (VROM), which is available through the Netherlands Scientific Statistical Agency. The research sample was representative of the Netherlands' population aged 18 and over and not living in an institution. The dataset included the 4-digit postcode of present residence. For the analysis of working arrangements we selected couple and family households in which both partners reported to be in employment, and male breadwinner households in which the male partner holds a paid job and the female partner is non-employed. We excluded female breadwinner households because numbers were too small to include as a separate category $(2.8 \%$ of all possible arrangements, leading to large standard errors). Comparison of models with and without the female breadwinner category showed no difference in the effects of the independent variables on the other working arrangements (not shown). For the analysis on commuting arrangements, we only selected couple and family households in which both partners reported to be in paid employment.

We selected households in which both partners are aged between 18 and 60. The upper age limit was chosen because there are very few households with two workers over 60 years old. We excluded households in which one or both partner(s) reported that they were a student, disabled or a pensioner; households who reported living with the parents of one of the partners; and same sex households (very small numbers). The final sample consisted of 28,240 households for the analysis of working arrangements and of 16,730 households for the analysis of commuting arrangements.

We made the working arrangements discussed at the start of the literature review operational by using a categorisation based on hours per week spent on paid work by each partner and symmetry in working hours between partners. Using official Statistics Netherlands definitions we define working fulltime as working 35 hours or more a week; a large part-time job is defined as working 20 to 35 hours a week; and a small part-time job is defined as working less than 20 hours a week. Combining working hours of two partners led to the following working arrangements: the symmetric fulltime arrangement, the female large part-time arrangement, the female small part-time arrangement and the male part-time arrangement. Although the focus is on dual earner arrangements, we also included the male breadwinner arrangement in which the male partner holds a fulltime job and the female partner has no job.

We made commuting arrangements operational based on the commuting time of each working partner and symmetry between commuting times of partners. We distinguished five categories of commuting arrangements: symmetric close, in which both partners commute less than 15 minutes; symmetric far, in which both partners commute more than 45 minutes; female very close in which the female partner commutes less than 15 minutes and the male partner commutes more than 45 minutes; female close, in which the female partner commutes up to 45 minutes and the male partner commutes more than 45 minutes; and other, a rest category, consisting of all remaining combinations, including arrangements in which the commuting time of females is equal or higher than their partner's commuting time. We realise that the above categorisation of working and commuting arrangements results in some loss of detail. However, we had to limit the number of categories for practical reasons and we believe that our categories do justice to decisions made on working and commuting in households. 
Because our dependent variables have unordered response categories we used multinomial logistic regression models to analyse working and commuting arrangements. In this type of model, each of the categories of the dependent variable is compared to a reference category. A higher parameter estimate B increases the odds ratio of one category compared to the reference category (Liao, 1994). In the model of working arrangements the category 'symmetric full-time' is the reference category and in the model of commuting arrangements 'symmetric close' is the reference category. For a full understanding of working and commuting arrangements, all significant contrasts between categories are presented in the last columns of the Table 2 and 3.

\section{Independent variables}

Table 1 presents the summary statistics and definitions of all the variables used in our models. Below we give more detail on the four spatial context variables used. Degree of urbanisation was measured in three categories: municipalities with less than 100,000 inhabitants and/or less than 1,500 addresses per square kilometre (reference category); strongly urbanized areas with between 1500 to 2500 addresses per square kilometre; and very strongly urbanized areas with more than 2500 addresses per square kilometre. The job access variable measures the number of jobs per job level within a travel time of 45 minutes by car over the road network from four digit postal codes. We allotted a measure of job access to all households on the basis of their residential location and the educational level of the highest educated partner (See Van Ham, 2001 for more details on the measure of job access used). We included job access for the partner with the highest level of education as this partner is most likely to have the highest earning potential and therefore drive household decisions with regard to work and commuting. We used 45 minutes as a threshold because this is the maximum time most people wish to commute (Van Ham 2001, Van Ommeren, 1996). We used travel time by car over the road network because more than $60 \%$ of all workers in the Netherlands commute by car (Statistics Netherlands, 2002). We also tested a measure of job access by train (only 10\% of commuters travel by train) but due to the high correlation between job access by car and job access by train it was not possible to include both in one model. Ideally we would also have liked to include a variable indicating access to a car, but this variable was not available on the household level.

The Randstad dummy indicates whether a household lives in the polynucleated urban system in the western part of the Netherlands. Finally, the regional unemployment variable measures the percentage of unemployment in 2002. Unemployment is defined as not working or working less than twelve hours a week and looking for work in the labour-market area of residence (18 labour market areas, see Statistics Netherlands, 2007). The regional unemployment rate is included to isolate effects of regional labour markets from other more generic effects of the spatial residential context.

$<<<$ Table 1 please about here $>>>$

\section{Results}

\section{Working arrangements}

Table 2 shows the results of a multinomial logistic regression model of working arrangements. The reference category is 'symmetric full-time'. The results show that with increasing age of the female partner, the most likely working arrangement is the breadwinner model, followed by the female small part-time model. The education effect confirms the hypothesis that the higher the level of education of the female partner, the more hours are 
worked in the household as a whole. Couples with a highly educated female are less likely to be in a female small part-time arrangement or in the breadwinner arrangement (compared to being in a symmetric full-time arrangement). Surprisingly, the effect of the female having a high level of education is more negative for the small part-time model than for the breadwinner model. This suggests that those highly educated women who don't have a large part-time or full-time job, tend to prefer not working at all over having a small part-time job. However, the result might also reflect the difficulty to find a suitable small part-time job when being more highly educated, since most small part-time jobs are lower level jobs. We also found a small positive effect of females having a lower secondary education on the likelihood to be in a female large part-time arrangement. But this effect was hardly significant. Interestingly, when the female partner has a high level of education, this increases the probability of a male part-time arrangement versus a symmetric fulltime arrangement. This might indicate a modern attitude towards work arrangements in such households.

$<<<$ Table 2 please about here $>>>$

A high female and male wage rate (earning per hour) have a negative impact on time spent on paid work on the household level. The higher the wage rate the more likely it is that a household is in a female or male part-time arrangement. The effect of female wage rate is strongest for the male part-time working arrangement compared to symmetric fulltime arrangement. The findings support the income effect rather than the substitution effect of wage rate. A high wage rate for men decreases the probability of the breadwinner model compared to the symmetric full-time and other arrangements. This indicates that male breadwinners are likely to have a relatively low income, possibly reflecting an association between low income and more traditional values with regard to gender roles.

When the female partner is older than the male partner, this positively influences the probability of being in a symmetric fulltime working arrangement. Such households are also less likely to be in a female small part-time arrangement compared to being in a female large part-time arrangement, which is in line with the hypothesis. As expected, households in which the female partner is equally well or more highly educated than the male partner are less likely to be in a working arrangement other than symmetric full-time. Such households are especially unlikely to be in a breadwinner arrangement. Contrary to what was suggested in another study (De Meester et al., 2007) we found no positive effect of the female being more highly educated on the probability to be in a male part-time working arrangement, except when compared to the breadwinner model.

We found a small negative effect on being in a female large part-time arrangement for households where the female partner earns more than the male partner. Although the other parameters are also negative as expected, they were not significant. These results confirm the hypothesis that homeownership increases the need to earn income and that, as a consequence, more time is being spent in paid work by both partners. Homeowners are less likely to be in a female small part-time arrangement, a male part-time arrangement and a breadwinner arrangement compared to the symmetric full-time arrangement than renters. Furthermore, being homeowner positively influences the likelihood of female large part-time arrangement versus a female small part-time arrangement.

As expected, compared to the other variables in the model, the presence and age of children in the household has a large effect on working arrangements. Having children, and in particular having young children, increases the probability to be in a part-time arrangement or the breadwinner arrangement, compared to the symmetric fulltime arrangement. Having children also increases the likelihood of a female small part-time arrangement versus a female large part-time arrangement. These findings indicate that on the household level, hours in paid 
work may be reduced because of time budget constraints. Having children also increases the likelihood of a female small part-time arrangement versus a traditional breadwinner model. Women seem to reduce hours in paid work when having children rather than leaving the paid labour force at all. The results did not support the hypothesis that having children leads to more hours of paid work by men. On the contrary, as can be seen in Table 2, having children increases the likelihood of a male part-time working arrangement. This can be seen as an indication that households move towards a more equal distribution of household tasks, especially when there are children in the household.

In line with our hypothesis on traditional values, we found religiosity to have a positive effect on the likelihood of couples being in the breadwinner model and the female small part-time model versus the symmetric full-time working arrangement. We also tested the working arrangement model without the male breadwinner category and found no difference in the effects of religiosity on the other categories. Also without the male breadwinner category religiosity has a positive effect on being in a female small part-time arrangement. As expected those belonging to an ethnic minority group are less likely to be in a working arrangement other than the symmetric full-time arrangement.

Next, a block of residential context variables - the main variables of interest - was included in the model. Living in a strongly urbanised area and a very strongly urbanised area was expected to facilitate symmetric fulltime arrangements because of the available facilities and services. The results indeed show that living in strongly urbanised areas, and especially in very strongly urbanised areas decreases the probability of female part-time arrangements and the breadwinner model, compared to the symmetric full-time model. Especially the negative effect of living in very strongly urbanised areas on the small female part-time arrangement is large. Based on these results it is impossible to say whether these findings are the result of opportunities or lifestyle. There is however some evidence of a lifestyle effect related to living in cities. As hypothesised, we found that living in a very strongly urbanised area increases the likelihood of a male part-time arrangement versus all other working arrangements. This result supports the lifestyle hypothesis rather than the opportunity hypothesis.

The effect of the job access variable is in line with the hypothesis that living in suburban areas situated in between large cities - locations with exceptionally good access to jobs within 45 minutes by car - decreases the likelihood of the small part-time arrangement and the breadwinner arrangement versus the symmetric full-time arrangement. The parameters of the small part time arrangement and the male part time arrangement are also negative, but not significant. Suburban locations with good job access facilitate the symmetric full time model, and it is likely that some dual earner couples choose such strategic residential locations because the good access to jobs is instrumental to their desire to have two full time jobs. We also ran a model using a measure of job access by train (not shown). As mentioned before, only $10 \%$ of all workers in the Netherlands commute by train, so this variable is only relevant for a minority of workers. The main difference between a model including job access by car and a model including job access by train is that the effect of living in a very strongly urbanised area disappears. The underlying reason for this is probably that very strongly urbanised areas combine good services with very good rail connections to other cities (as major railway stations are always located in the city centre). So the good job access by train serves as a proxy for good services or the other way around.

We found no effect of living in the Randstad on working arrangements. We did find that a high regional unemployment rate increases the likelihood of a male part-time arrangement versus the symmetric full-time arrangement and decreases the likelihood of the breadwinner model. 


\section{Commuting arrangements}

Table 3 shows the results of a multinomial logistic regression model of commuting arrangements. The population under study only includes households in which both partners have a paid job. The reference category consists of those in symmetric close commuting arrangements. With increasing age of the female partner, dual earner households are less likely to be in a commuting arrangement other than the symmetric close arrangement. With increasing level of education of the female partner, dual earners are more likely to have a commuting arrangement other than the symmetric close commuting arrangement. Dual earner households where the female is highly educated are especially likely to have a symmetric far commuting arrangement compared to the symmetric close arrangement. These results suggest that highly educated women are likely to have a long commute themselves or have partners with long commutes. We found small negative effects of a high male wage rate on the female closer and other arrangements.

$<<<$ Table 3 please about here $>>>$

Differences in age between partners and wage differences between partners do not lead to any meaningful effects on commuting arrangements. In households where the female partner is equally or more highly educated than the male partner, all commuting arrangements are less likely than the symmetric close arrangement. In line with our expectations, homeownership was found to have a positive effect on all commuting arrangements compared to the symmetric close arrangement. Households owning their home are likely to have at least one partner with a long commute. This is in line with the idea that homeowners, and especially dual earner homeowners, have a limited commuting tolerance, and therefore have long commutes.

The presence of young children in the household decreases the probability of all commuting arrangements compared to the symmetric close arrangement. This indicates that when having young children, both partners try to save on commuting time as a strategy to relax the pressure of household responsibilities. Surprisingly, the effects of having a very young child (up to 5 years of age) is about the same for all commuting arrangements compared to the symmetric close arrangement. Having children in the age category 12 to 18 years of age increases the probability of a female much closer commuting arrangement versus a symmetric far commuting arrangement. A possible cause is that the mobility needs of children in this age group place a high burden on the time budget of parents.

Religious households are less likely to be in commuter arrangements other than the symmetric close arrangement. So when both partners in a religious couple have a paid job, they tend to work relatively close to home. Interestingly, we also found religious households to be more likely to be in a female small part-time and male breadwinner arrangement (see Table 2). We believe that the effect of being religious on both working arrangements and commuting arrangements can be explained from the idea of religious couples having more traditional family values. On the one hand, traditional values lead to the male partner to work most hours in a paid job while the female partner spends most time at home (with children). On the other hand, when both partners work, religious couples tend to have relatively short commutes so that more time is left for family life. As expected, belonging to an ethnic minority group has a positive effect on all commuting arrangements compared to the symmetric close arrangement. Ethnic minority households are especially likely to be in a symmetric far commuting arrangement which is likely to reflect that ethnic minorities have less choice on the labour market.

Next, a block of residential context variables - the main variables of interest - was included in the model. The results show that living in strongly urbanised and very strongly 
urbanised areas has a positive effect on all commuting arrangements compared to the symmetric close arrangement. So living in an urbanized area is associated with a long commute for at least one partner. A high job access within 45 minutes travel time by car has a positive effect on the probability to be in a symmetric far or in a female close arrangement. Since areas with very good job access are mainly suburban areas in between large cities, the results seem to support the 'dual earner strategy' hypothesis rather than the 'spatial entrapment' thesis for commuting arrangements. Those living in the Randstad are more likely to be in a symmetric far or a female closer commuting arrangement, compared to the symmetric close arrangement. This is most likely due to heavy congestion on the road network in this part of the Netherlands.

\section{The effect of working arrangements on commuting arrangements}

As a last step in Table 3, we tested whether working arrangements have an effect on commuting arrangements. The male breadwinner arrangement was excluded, because the model refers to dual earner households only. On the one hand we expected that more time spent on paid work would result in more time spent on commuting; on the other hand, from a time budget perspective, we expected that more time spent in paid work would result in less time spent on commuting. The results show that compared to those in a symmetric full-time arrangement, all other working arrangements are more likely to be in a commuter arrangement with at least one partner having a long commute. This provides some support for the time budget hypothesis: those in symmetric full-time working arrangements are also those most likely to be in symmetric close commuting arrangements. This is an indication that a symmetric fulltime working arrangement is less feasible when both partners have to commute long distances, because the available time budget is already pushed to its limits by the time spent in paid work. Saving time on commuting by both partners might be a strategy to enable both partners to work full-time. Being in a female small part-time working arrangement compared to being in a symmetric full-time arrangement increases the probability to be in an asymmetric commuting arrangement where the female works closer or much closer than the male partner. This may suggest that it is not worth having a long commute for a part-time job. Of course, this effect can also be the result of a constrained time space budget. Having a male part-time arrangement instead of a symmetric fulltime arrangement increases the likelihood of all commuting arrangements, other than the symmetric close arrangement.

\section{Conclusion}

We found significant effects of the residential context on working and commuting arrangements. We found that in very strongly urbanised areas it is more likely that households have a working arrangement where the male partner works part-time than in other areas. This is in line with the expectation that male part-time arrangements would gain importance in large cities expressed almost 15 years ago by Droogleever Fortuijn (1993), based on her qualitative study. We also found that in very strongly urbanised areas it is more likely that households have a working arrangement where both partners work fulltime. Both findings might be due to the presence in large cities of a more egalitarian attitude towards task division between partners. In contrast to what was suggested in earlier qualitative studies of urban dual earners in the Netherlands, we found no indication that having access to a great number of jobs at a close distance also leads to short commutes for both partners. We found that living in very urbanised areas increases the likelihood that both partners have a long commute. We also found that living in areas with very good job access - mainly suburban areas between the larger cities - makes it more likely that one or both partners have a long commute. This 
supports the idea that suburban locations in between large cities are strategic locations for dual career households from a life course perspective, since from such 'in-between-areas' several large job markets can be accessed for those willing to invest in commuting. This increases chances of finding suitable jobs for both partners, also on the long term, without having to change residence.

Analysing the effect of working arrangements on commuting arrangements showed that those couples having a symmetric full-time working arrangement are also those most likely to have a symmetric close commuting arrangement. This indicates that time spent on paid work is traded off for time spent on commuting because of time constraints on the household level. Having a male part-time or large female part-time working arrangement increases the likelihood of all other commuting arrangements than the symmetric close arrangement. A possible explication is that in households where one of the partners works part-time, time constraints are less stringent, enabling at least one partner to have a longer commute.

This study contributed to our understanding of individual careers in several ways. First, we studied both working and commuting in a household context, looking at working and commuting arrangements between partners in couple and family households. This does more justice to the reality of dual earner households - where decisions on work and commuting are made in a household context - than studying working and commuting on the level of individuals. We showed that career decisions are not independent and that careers of individuals in households should be analysed jointly. Second, we analysed the impact of the residential context on working and commuting arrangements using quantitative data and we showed that there is spatial variation in working and commuting arrangements. Third, we analysed the impact of working arrangements on commuting arrangements, acknowledging that decisions on working arrangements within households influence commuting arrangements. This has improved our understanding of how workers trade off commuting time and working time on the household level.

The data we used come from The Netherlands Housing Demand Survey. The data is unique for two reasons. First, it contains details on work and commuting for both partners in a couple or family household; and second, the data is geocoded, allowing researchers to link residential context variables to households at a low spatial level. As the name suggest, the survey is not designed to study working and commuting arrangements. It lacks specific questions on how households came to certain working and commuting arrangements limiting the depth of our analyses. Also, as the data is cross-sectional, it does not contain information on the ordering of decisions on commuting, work and residential locations. As we pointed out earlier, it is very likely that some couples choose certain residential contexts because they facilitate their desired working and commuting arrangements. This reversed causality does not invalidate our findings as it still means that the residential context is instrumental to the arrangements, but using a longitudinal design would help to unravel the ordering of decisions.

Our findings have potential implications for policies aimed at encouraging full-time working arrangements. We found that households in urbanised areas and areas with good job access are the most likely to be in symmetric full-time (or female large part-time) working arrangements. This shows that residential contexts with a rich opportunity structure are instrumental to maximising working hours on the household level. We also found - after controlling for residential context variables - that households in symmetric full-time working arrangements are the most likely to be in symmetric close commuting arrangements. This reflects the time budget constraints of dual earners. The limited commuting (and migration) tolerance of those in symmetric full-time arrangements could lead to an underutilisation of skills as workers cannot invest in commuting to get the best possible job matching their skills. From previous research we know that residential locations with good access to job 
opportunities - strategic residential locations in between large cities - have a positive effect on occupational mobility (Van Ham, 2001). We found that locations with good job access are instrumental to full time working arrangements, but also have a positive effect on the probability to be in symmetric far commuting arrangements. This confirms the idea that workers living at these strategic locations invest in commuting to get the best possible match between their skills and a job. At the same time it means that living on these locations imposes a heavy weight on household's available time budget, especially when the opportunity structure of suburban locations with respect to amenities like shops, schools, daycare, and services is not particularly rich. Spatial planning could facilitate symmetric full time working arrangements and at the same time limit commuting by creating amenity rich residential environments with good access to job opportunities. This means investing in compact residential environments, with good access to more than one concentration of employment opportunities. At the same time, encouraging flexible working schemes, allowing people to work from home, and investing in homes suitable for working from home (office space and fast internet) would help to reduce the time stress of symmetric full time couples.

\section{References}

Andriessen I, Dagevos J, Nievers E, Boog I, 2007 Discriminatiemonitor niet-westerse allochtonen op de arbeidsmarkt 2007 [translation: Discrimination Monitor 2007 nonWestern ethnic minorities on the labour market] (SCP, The Hague/Rotterdam)

Becker G S, 1962, "Investment in human capital: a theoretical analysis", The Journal of Political Economy 70 (5) 9-49

Becker G S, 1965, "A theory of the allocation of time" Economic Journal 75 493-517

Becker G S, 1981 A treatise on the family (Harvard University Press, Cambridge, MA)

Blundell R, MaCurdy T, 1999, Labor Supply: a Review of Alternative Approaches pp 15591689 In: O Ashenfelter and D Card, Handbook of labor economics (Elsevier, Amsterdam)

Brun J, Fagnani, J, 1994, "Lifestyles and locational choices - Trade-offs and compromises: A case-study of middle-class couples living in the Ile-de-France region" Urban Studies 31 (6) 921-934

Clark WAV, Kuijpers-Linde M, 1994, "Commuting in Restructuring Urban Regions" Urban Studies 31 (3) 465-483

Clarkberg M, Moen, P, 2001, “Understanding the Time-Squeeze: Married Couples' Preferred and Actual Work-Hour Strategies" American Behavioral Scientist 44 (7) 1115-1135

Costa D L, Kahn M E, 2000, "Power Couples: Changes in the Locational Choice of the College Educated, 1940-1990", The Quarterly Journal of Economics 115(4) 1287-1315

De Meester E, Mulder C H, Fortuijn, J D, 2007, "Time spent in paid work by women and men in urban and less urban contexts in the Netherlands", Tijdschrift voor Economische en Sociale Geografie 98 (5) 585-602

Droogleever Fortuijn J, 1993 Een druk bestaan. Tijdsbesteding en ruimtegebruik van tweeverdieners met kinderen [translation: A busy life: the use of time and space in dualearner families] (Amsterdam University Press, Amsterdam)

Duyvendak J W, Stavenuiter M M J, 2004 Reconciliation of Working life and Family Life. Working Fathers, Caring Men (Verwey-Jonker Instituut, Rotterdam)

England K V L, 1993, "Suburban pink collar ghettos: The spatial entrapment of women?" Annals of the Association of American Geographers 83 (2) 225-242

Green A E, 1997, "A question of compromise? Case study evidence on the location and mobility strategies of dual career households" Regional Studies 31 (7) 641-657 
Gronau R, 1977, "A theory of the allocation of time revisited", Journal of Political Economy 85 (6) 1099-1123

Hägerstrand T, 1970, "What about people in regional science?" Papers of the Regional Science Association 24 7-21

Hanson S, Johnston I, 1985, "Gender differences in work-trip length explanations and implications" Urban Geography 6 (3) 193-219

Hanson S, Pratt A C, 1988, "Reconceptualizing the links between home and work in urban geography" Economic Geography 64 (4) 299-321

Hanson S, Pratt G, 1995 Gender, Work, and Space (Routledge, London)

Helderman A C, Van Ham M, Mulder C H, 2006, "Migration and home ownership" Tijdschrift voor Economische en Sociale Geografie 97 (2) 107-121

Hochschild A R, Machung A, 1989 The Second Shift (Viking, New York)

Jarvis H, 1999, "The tangled webs we weave: household strategies to co-ordinate home and work" Work, Employment \& Society 13 (2) 225-247

Jarvis H, 2005, "Moving to Londen time. Household co-ordination and the infrastructure of everyday life" Time \& Society 14 (1) 133-154

Johnston-Anumonwo I, 1992, "The Influence of Household Type on Gender Differences in Work Trip Distance" The Professional Geographer 44 (2) 161-169

Karsten L, 2003, "Family gentrifiers: Challenging the city as a place simultaneously to build a career and to raise children" Urban Studies 40 (12) 2573-2584

Keuzenkamp S, Hooghiemstra E, 2000 De kunst van het combineren: Taakverdeling onder partners [translation: The art of combining: Task division between partners] (Sociaal en Cultureel Planbureau, Den Haag)

Knijn T, 2003, "Challenges and risks of individualisation in The Netherlands", Social Policy \& Society 3 (1) 57-65

Liao T F, 1994 Interpreting Probability Models Logit, Probit, and Other Generalized Linear Models (Sage, Thousand Oaks)

MacLafferty S, Preston V, 1992, "Spatial mismatch and labor market segmentation for African-American and Latina women" Economic Geography

Madden J F, 1981, "Why Women Work Closer to Home" Urban Studies 18 (2) 181-194

McDowell L, 2004, "Work, workfare, work/life balance and ethic of care" Progress in Human Geography 28 (2) 145-163

Mincer J, Polachek S, 1974, "Family investments in human capital: Earnings of women" The Journal of Political Economy 82 (2) 76-108

Moen P, 2003 It's About Time. Couples and Careers (Cornell University Press, Ithaca)

Presser H, 2006, Employment in a 24/7 economy: challenges for the family In: D Perrons, C Fagan, L McDowell, K Ray and K Ward, Gender divisions and working time in the new economy (Edward Elgar, Cheltenham)

Rouwendal J, Nijkamp P, 2004, "Living in Two Worlds: A Review of Home-to-Work Decisions" Growth and Change 35 (3) 287-303

Schwanen T, 2006, "On `arriving on time', but what is `on time'?" Geoforum 37 (6) 882-894

Schwanen T, 2007, "If you pick up the children, I'll do the groceries: spatial differences in between-partner interactions in out-of-home household activities." Environment \& Planning A 39 (11) 2754

Schwanen T, Dijst M, 2002, "Travel-time ratios for visits to the workplace: the relationship between commuting time and work duration" Transportation Research Part A 36 573592

Schwanen T, Dijst M, Dieleman F M, 2002, "A microlevel analysis of residential context and travel time" Environment and Planning A 34 1487-1507 
SCP, 1999 Naar andere Tijden? Tijdsbesteding en Tijdsordening in Nederland [translation: the restructuring of time], 1975-1995 (Elsevier, The Hague)

Statistics Netherlands (CBS), 2002, http://www.cbs.nl/en-GB/menu/themas/verkeervervoer/publicaties/artikelen/archief/2004/2004-1393-wm.htm HTTP://WWW.CBS.NL[JULY 17]

Statistics Netherlands (CBS), 2007, Statline, the statistical database on the Netherlands, http://statline.cbs.nl/ [2007, January 17]

Tivers J, 1985 Women Attached: The Daily Lives of Women with Young Children (Croom Helm, London)

Turner T, Niemeier D, 1997, "Travel to work and household responsibility: New evidence" Transportation 24 397-419

Van der Lippe T, Jager A, Kops Y, 2006, "Combination pressure - The paid work-family balance of men and women in European countries" Acta Sociologica 49 (3) 303-319

Van der Lippe T, Siegers, J J, 1994, "Division of household and paid labour between partners: Effects of relative wage rates and social norms" Kyklos 47 (1) 109-136

Van der Valk J, 2005, "Arbeidsdeelname van paren [translation: Labor force participation of couples]" Sociaal-Economische Trends [Socio-Economic Trends] 27-31

Van Ham M, 2001, "Workplace mobility and occupational achievement" International Journal of Population Geography 7 295-306

Van Ham M, Hooimeijer P, Mulder C H, 2001a, "Urban form and job access: Disparate realities in the Randstad" Tijdschrift voor Economische en Sociale Geografie 92 (2) 231-246

Van Ham M, Mulder C H, Hooimeijer P, 2001b, "Spatial flexibility in job mobility: Macrolevel opportunities and microlevel restrictions" Environment and Planning A $\mathbf{3 3}$ 921-940

Van Ham M, 2002 Job Access, Workplace Mobility, and Occupational Achievement (Eburon, Delft)

Van Ham M, Hooimeijer P, 2005 Spatial barriers and labour flexibility: individual restrictions and market constraints on job mobility (Directie ruimtelijk Economisch Beleid, Ministry of Economic Affairs)

Van Ham M, Büchel F, 2006, "Unwilling or unable? spatial and socio-economic restrictions on females labour market access" Regional studies: journal of the Regional Studies Association 40 (3) 345-357

Van Ommeren J, 1996, Commuting and Relocation of Jobs and Residences: A Search Perspective (Vrije Universiteit, Amsterdam)

Van Wel F and Knijn T, 2006, "Transitional Phase or New Balance" Journal of Family Issues 27 (5) 633-651

Visser J, 2002, "The first part-time economy in the world: a model to be followed?" Journal Of European Social Policy 12 (1) 23-42

Warren T, 2007, "Conceptualizing breadwinning work" Work Employment Society 21 (2) 317-336 
Table 1. Descriptives of the independent variables ${ }^{\mathrm{a}}$

\begin{tabular}{|c|c|c|c|c|c|}
\hline & $\%$ & Min & Max & Mean & Std. Dev. \\
\hline \multicolumn{6}{|l|}{ Working arrangements $(\mathrm{N}=\mathbf{2 8 , 2 4 0})$} \\
\hline Symmetric fulltime & 20.3 & & & & \\
\hline Female large part-time (PT) & 30.9 & & & & \\
\hline Female small part-time (PT) & 18.5 & & & & \\
\hline Male part-time (PT) & 7.5 & & & & \\
\hline Breadwinner model & 22.8 & & & & \\
\hline \multicolumn{6}{|l|}{ Commuting arrangements $(\mathrm{N}=16,730)$} \\
\hline Symmetric close & 8.2 & & & & \\
\hline Symmetric far & 17.7 & & & & \\
\hline Female partner much closer & 9.0 & & & & \\
\hline Female partner closer & 25.7 & & & & \\
\hline Other & 39.4 & & & & \\
\hline \multicolumn{6}{|l|}{ Socio-economic variables } \\
\hline Age female partners (in years) & & 15.00 & 59.00 & 38.29 & 9.47 \\
\hline \multicolumn{6}{|l|}{ Educational level female } \\
\hline Up to primary & 4.0 & & & & \\
\hline Lower secondary & 31.4 & & & & \\
\hline Upper secondary & 36.9 & & & & \\
\hline Higher vocational and university & 27.7 & & & & \\
\hline Wage rate female partner $(\mathrm{N}=16,730)^{\mathrm{b}}$ & & 0.00 & 576.92 & 10.81 & 7.23 \\
\hline Wage rate male partner ${ }^{b}$ & & 0.00 & 900.00 & 10.09 & 9.46 \\
\hline \multicolumn{6}{|l|}{ Age difference between partners } \\
\hline Female younger & 72.0 & & & & \\
\hline Equally old & 11.1 & & & & \\
\hline Female older & 16.9 & & & & \\
\hline \multicolumn{6}{|l|}{ Educational difference between partners } \\
\hline Female lower educated & 29.7 & & & & \\
\hline Equally educated & 47.7 & & & & \\
\hline Female more highly educated & 22.6 & & & & \\
\hline Wage rate female $>=$ wage rate male & & & & & \\
\hline $\begin{array}{l}(\mathrm{N}=16,730) \\
\text { At least one partner is homeowner }\end{array}$ & $\begin{array}{l}50.2 \\
75.6\end{array}$ & & & & \\
\hline
\end{tabular}

\begin{tabular}{lr}
\hline Gender role variables & 75.6 \\
Number of inliving children & \\
No inliving children & 46.5 \\
Youngest inliving child up to 5 & 24.7 \\
Youngest inliving child 5 to 12 & 17.5 \\
$\quad$ Youngest inliving child 12 to 18 & 11.4 \\
\hline Background variables $^{\text {At least one partner is religious }}{ }^{\mathrm{c}}$ & \\
At least one partner is non-western immigrant $^{\mathrm{d}}$ & 28.1 \\
\hline
\end{tabular}

\section{Residential context variables}

Degree of urbanisation

Not urbanized up to strongly urbanized $\quad 76.2$

Strongly urbanized $\quad 11.9$

Very strongly urbanized $\quad 11.9$

Job access highest educated partner within 45

minutes over the road $(* 100,000)$

Lives in the Randstad region

\begin{tabular}{rrrrr}
36.3 & 0.01 & 10.84 & 3.19 & 2.22 \\
& 3.1 & 6.80 & 4.14 & 0.79 \\
\hline
\end{tabular}

Regional unemployment rate household is categorised as religious if one or both partners regularly attend religious services;

${ }^{\mathrm{d}}$ A non-western immigrant is defined as born (or with parent born) in Turkey, Africa, Latin America, and Asia (Indonesia and Japan excluded). Definition from Statistics Netherlands.

Source: Housing Demand Survey (2002) and the ABF Real Estate Monitor (2004), own calculations. 
Table 2. Multinomial logistic regression of working arrangements in couple and family hh (ref category = symmetric fulltime), $\mathrm{N}=28,240$.

\begin{tabular}{|c|c|c|c|c|c|c|c|c|c|c|c|c|c|}
\hline \multirow[b]{2}{*}{ Intercept } & \multicolumn{2}{|c|}{$\begin{array}{l}\text { Model 1 } \\
\text { Female large part } \\
\text { time } \\
\end{array}$} & \multicolumn{2}{|c|}{$\begin{array}{l}\text { Model } 2 \\
\text { Female small } \\
\text { part time }\end{array}$} & \multicolumn{2}{|c|}{$\begin{array}{l}\text { Model } 3 \\
\text { Male part time }\end{array}$} & \multicolumn{2}{|c|}{$\begin{array}{l}\text { Model } 4 \\
\text { Breadwinner }\end{array}$} & \multirow{2}{*}{$\begin{array}{l}\mathrm{vs} 1 \\
\star \star \star \\
\end{array}$} & \multirow{2}{*}{$\begin{array}{l}\text { 3vs1 } \\
\star \star \star \\
\end{array}$} & \multirow{2}{*}{$\begin{array}{l}\text { 4vs1 } \\
\text { ** } \\
\end{array}$} & \multirow{2}{*}{$\begin{array}{l}2 \mathrm{vs4} \\
\\
\star \star \star \\
\end{array}$} & \multirow{2}{*}{$\begin{array}{l}3 \mathrm{vs} 4 \\
\star \star \star\end{array}$} \\
\hline & -1.618 & $* * *$ & - & $* * *$ & -4.504 & $* * *$ & -1.232 & $* * *$ & & & & & \\
\hline \multicolumn{14}{|l|}{ Socio-economic variables } \\
\hline Age female partner (in years) & 0.043 & $* * *$ & 0.091 & $* * *$ & 0.065 & $* * *$ & 0.123 & $* * *$ & $* * *$ & $* * *$ & *** & $* * *$ & $\star \star \star *$ \\
\hline \multicolumn{14}{|l|}{ Educational level female (ref=up to primary) } \\
\hline Lower secondary & 0.253 & $*$ & - & & 0.004 & & -0.097 & & ** & & *** & & \\
\hline Upper secondary & 0.209 & & - & $* * *$ & 0.103 & & -0.507 & $* * *$ & $\star * *$ & & $* * *$ & & $\star \star \star *$ \\
\hline Higher vocational and university & -0.216 & & - & $* * *$ & 0.386 & $* *$ & -0.861 & $* * *$ & $* * *$ & 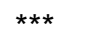 & $* * *$ & *** & $* * *$ \\
\hline Wage rate female partner & 0.024 & $* * *$ & 0.035 & $* * *$ & 0.046 & $* * *$ & a & & $\star * *$ & $* * *$ & $* * *$ & $* * *$ & $* * *$ \\
\hline Wage rate male partner & 0.007 & $*$ & 0.020 & $* * *$ & 0.023 & $* * *$ & -0.095 & $* * *$ & $* * *$ & $* * *$ & $* * *$ & $* * *$ & $* * *$ \\
\hline \multicolumn{14}{|l|}{ Age dif partners (ref=female younger) } \\
\hline Equally old & -0.082 & & 0.012 & & -0.147 & & -0.041 & & & & & & \\
\hline Female older & -0.177 & $* * *$ & - & $* * *$ & -0.246 & $* * *$ & -0.529 & $* * *$ & $* * *$ & & *** & * & $* * *$ \\
\hline \multicolumn{14}{|c|}{ Educational dif partners (ref=female lower educated) } \\
\hline Partner equally educated & -0.199 & $* * *$ & - & $* * *$ & -0.256 & $* * *$ & -0.477 & $* * *$ & & & *** & *** & $\star \star \star *$ \\
\hline Female partner more highly educated & -0.199 & $* * *$ & - & $* * *$ & -0.323 & $* * *$ & -0.788 & $* * *$ & & & *** & *** & $* * *$ \\
\hline Wage rate female $>=$ man & -0.099 & $* *$ & - & & -0.027 & & $\mathrm{~b}$ & & & & $* * *$ & $* * *$ & $\star * *$ \\
\hline At least one partner is homeowner & -0.040 & & - & $* * *$ & -0.597 & $* * *$ & -0.326 & $* * *$ & *** & $* * *$ & *** & * & $\star \star \star *$ \\
\hline \multicolumn{14}{|l|}{ Gender role variables } \\
\hline \multicolumn{14}{|l|}{ Age of inliving children (ref=no inliv child) } \\
\hline Youngest inliv child up to 5 & 1.944 & $* * *$ & 3.625 & $* * *$ & 2.246 & $* * *$ & 3.195 & $* * *$ & $\star * *$ & *** & *** & *** & $* \star *$ \\
\hline Youngest inliv child 5 to 12 & 1.473 & $* * *$ & 2.841 & $* * *$ & 1.498 & $* * *$ & 2.178 & $* * *$ & $* * *$ & & $* * *$ & $* * *$ & $* * *$ \\
\hline Youngest inliv child 12 to 18 & 0.870 & $* * *$ & 1.496 & $* * *$ & 0.579 & $* * *$ & 0.971 & $* * *$ & $* * *$ & $* * *$ & * & $* * *$ & $* * *$ \\
\hline \multicolumn{14}{|l|}{ Background variables } \\
\hline At least one partner is religious & 0.074 & & 0.354 & $* * *$ & -0.041 & & 0.427 & $* * *$ & $* * *$ & * & *** & & *** \\
\hline At least one partner is non-west immigrant & -0.460 & $* * *$ & - & $* * *$ & -0.353 & $* * *$ & -0.140 & $*$ & *** & & *** & *** & ** \\
\hline \multicolumn{14}{|c|}{ Residential context variables } \\
\hline \multicolumn{14}{|c|}{ Degree of urbanization (ref=less than strongly urbanized) } \\
\hline Strongly urbanized & -0.051 & & - & $* * *$ & 0.100 & & -0.272 & $* * *$ & $* * *$ & $* *$ & $\star * *$ & & $* * *$ \\
\hline Very strongly urbanized & -0.176 & $* * *$ & - & $* * *$ & 0.197 & $* *$ & -0.312 & $* * *$ & $\star * *$ & $* * *$ & * & *** & $* * *$ \\
\hline Job access highest educ partner within $45 \mathrm{~min}$ & -0.015 & & - & $* * *$ & -0.018 & & -0.028 & $*$ & $* * *$ & & & $* * *$ & \\
\hline Lives in the Randstad region & 0.063 & & 0.115 & & -0.031 & & 0.041 & & & & & & \\
\hline Regional unemployment rate & -0.022 & & - & & 0.082 & $* * *$ & -0.058 & $* *$ & & $* * *$ & & & $* * *$ \\
\hline -2 Log Likelihood & $68,728.4$ & & & & & & & & & & & & \\
\hline${ }^{\mathrm{A}}$ The mean of wage rate was put in the equation & & & & & & & & & & & & & \\
\hline \multicolumn{14}{|c|}{${ }^{\mathrm{B}}$ The parameter of wage rate difference is not to be interpreted } \\
\hline$*=\mathrm{p}<0.10, * *=\mathrm{p}<0.05 ; * * *=\mathrm{p}<0.01$ & & & & & & & & & & & & & \\
\hline
\end{tabular}

Source: Housing Demand Survey (2002) and the ABF Real Estate Monitor (2004), own calculations. 
Table 3. Multinomial logistic regression of commuting arrangements in couple and family hh (ref category = symmetric close), N=16,730.

\begin{tabular}{|c|c|c|c|c|c|c|c|c|c|c|c|c|c|}
\hline \multirow{2}{*}{ Intercept } & \multicolumn{2}{|c|}{$\begin{array}{l}\text { Model 1 } \\
\text { Symmetric far }\end{array}$} & \multicolumn{2}{|c|}{$\begin{array}{l}\text { Model } 2 \text { Female } \\
\text { much closer }\end{array}$} & \multicolumn{2}{|c|}{$\begin{array}{l}\text { Model 3 } \\
\text { Female closer }\end{array}$} & \multicolumn{2}{|c|}{$\begin{array}{l}\text { Model } 4 \\
\text { Other }\end{array}$} & \multirow[t]{2}{*}{$2 \mathrm{vs} 1$} & \multirow{2}{*}{$\begin{array}{l}\text { 2vs1 } \\
* * *\end{array}$} & \multirow{2}{*}{$\begin{array}{l}\text { 4vs1 } \\
* * *\end{array}$} & \multirow{2}{*}{$\begin{array}{l}\text { 3vs2 } \\
* * * \\
\end{array}$} & \multirow{2}{*}{$\begin{array}{l}\mathbf{4 v s 2} \\
* * *\end{array}$} \\
\hline & 0.780 & $* *$ & 0.508 & & 1.877 & $* * *$ & 2.409 & $* * *$ & & & & & \\
\hline \multicolumn{14}{|l|}{ Socio-economic variables } \\
\hline Age female partner (in years) & -0.045 & $* * *$ & -0.031 & $* * *$ & -0.039 & $* * *$ & -0.039 & $* * *$ & $* * *$ & $*$ & $* *$ & $* *$ & \\
\hline \multicolumn{14}{|l|}{ Educational level female (ref=up to primary) } \\
\hline Lower secondary & 0.110 & & 0.112 & & 0.052 & & 0.117 & & & & & & \\
\hline Upper secondary & 0.733 & $* * *$ & 0.499 & $* *$ & 0.422 & $* *$ & 0.445 & $* * *$ & & $*$ & $*$ & & \\
\hline Higher vocational and university & 1.784 & $* * *$ & 1.053 & $* * *$ & 0.897 & $* * *$ & 0.923 & $* * *$ & $* * *$ & $* * *$ & $* * *$ & & \\
\hline Wage rate female partner & 0.008 & & 0.002 & & -0.006 & & -0.008 & & & $* * *$ & $* * *$ & & $*$ \\
\hline Wage rate male partner & -0.002 & & -0.007 & & -0.009 & $* *$ & -0.014 & $* * *$ & & $*$ & $* * *$ & & \\
\hline \multicolumn{14}{|l|}{ Age dif partners (ref=female younger) } \\
\hline Equally old & 0.047 & & -0.086 & & -0.022 & & -0.073 & & & & $*$ & & \\
\hline Female older & 0.059 & & 0.181 & $*$ & 0.061 & & 0.087 & & & & & & \\
\hline \multicolumn{14}{|c|}{ Educational dif partners ( $\mathrm{ref}=$ female lower educated) } \\
\hline Partner equally educated & -0.426 & $* * *$ & -0.509 & $* * *$ & -0.322 & $* * *$ & -0.120 & & & & $* * *$ & $* * *$ & $* * *$ \\
\hline Female partner more highly educated & -0.920 & $* * *$ & -0.773 & $* * *$ & -0.513 & $* * *$ & -0.102 & & & $* * *$ & $* * *$ & $* * *$ & $* * *$ \\
\hline Wage rate female $>=$ man & 0.066 & & 0.043 & & -0.009 & & -0.016 & & & & & & \\
\hline At least one partner is homeowner & 0.333 & $* * *$ & 0.275 & $* * *$ & 0.324 & $* * *$ & 0.174 & $* *$ & & & $* * *$ & & \\
\hline \multicolumn{14}{|l|}{ Gender role variables } \\
\hline \multicolumn{14}{|l|}{ Age of inliving children (ref=no inliv child) } \\
\hline Youngest inliv child up to 5 & -0.690 & $* * *$ & -0.579 & $* * *$ & -0.757 & $* * *$ & -0.632 & $* * *$ & & & & $* *$ & \\
\hline Youngest inliv child 5 to 12 & -0.804 & $* * *$ & -0.283 & $* * *$ & -0.401 & $* * *$ & -0.493 & $* * *$ & $* * *$ & $* * *$ & $* * *$ & & $* * *$ \\
\hline Youngest inliv child 12 to 18 & -0.241 & $* *$ & 0.234 & * & 0.107 & & -0.063 & & $* * *$ & $* * *$ & $* *$ & & $* * *$ \\
\hline \multicolumn{14}{|l|}{ Background variables } \\
\hline At least one partner is religious & -0.317 & $* * *$ & -0.237 & $* * *$ & -0.277 & $* * *$ & -0.223 & $* * *$ & & & $*$ & & \\
\hline At least one partner is non-west immigrant & 0.987 & $* * *$ & 0.381 & $* *$ & 0.561 & $* * *$ & 0.547 & $* * *$ & $* * *$ & $* * *$ & $* * *$ & & \\
\hline \multicolumn{14}{|c|}{ Residential context variables } \\
\hline \multicolumn{14}{|c|}{ Degree of urbanization (ref=less than strongly urbanized) } \\
\hline Strongly urbanized & 0.484 & $* * *$ & 0.263 & $* *$ & 0.454 & $* * *$ & 0.455 & $* * *$ & $* *$ & & & $* *$ & $* *$ \\
\hline Very strongly urbanized & 0.273 & $* *$ & -0.049 & & 0.377 & $* * *$ & 0.612 & $* * *$ & $* * *$ & & $* * *$ & $* * *$ & $* * *$ \\
\hline Job access highest educ partner within $45 \mathrm{~min}$ & 0.130 & $* * *$ & 0.100 & $* * *$ & 0.055 & $* * *$ & 0.025 & & & $* * *$ & $* * *$ & $* *$ & $* * *$ \\
\hline Lives in the Randstad region & 0.375 & $* * *$ & 0.135 & & 0.256 & $* * *$ & 0.243 & $* * *$ & $* *$ & & * & & \\
\hline Regional unemployment rate & 0.049 & & -0.106 & $* *$ & -0.058 & & -0.013 & & $* * *$ & $* * *$ & $* *$ & & $* * *$ \\
\hline \multicolumn{14}{|l|}{ Working arrangements $($ ref $=$ symmetric } \\
\hline Female large part-time arrangement & 0.546 & $* * *$ & 0.928 & $* * *$ & 0.937 & $* * *$ & 0.653 & $* * *$ & $* * *$ & $* * *$ & * & & $* * *$ \\
\hline Female small part-time arrangement & 0.098 & & 1.239 & $* * *$ & 1.122 & $* * *$ & 0.545 & $* * *$ & $* * *$ & $* * *$ & $* * *$ & & $* * *$ \\
\hline Male part-time arrangement & 0.766 & $* * *$ & 0.796 & $* * *$ & 0.993 & $* * *$ & 0.855 & $* * *$ & & $* * *$ & & & \\
\hline -2 Log Likelihood & 46,77 & 3.217 & & & & & & & & & & & \\
\hline
\end{tabular}

-2 Log Likelihood

$46,778.217$

$*=\mathrm{p}<0.10, * *=\mathrm{p}<0.05 ; * * *=\mathrm{p}<0.01$

Source: Housing Demand Survey (2002) and the ABF Real Estate Monitor (2004), own calculations. 